\title{
ANALISIS PENGUNGKAPAN CORPORATE SOCIAL RESPONSIBILITY BERDASARKAN GLOBAL REPORTING INITIATIVES (GRI): STUDI KASUS PERUSAHAAN TAMBANG BATUBARA BUKIT ASAM (Persero) TBK DAN TIMAH (Persero) TBK
}

\author{
Nuraini Sari \\ Accounting and Finance Department, Faculty of Economic and Communication, BINUS University \\ Jln. K.H. Syahdan No. 9, Palmerah, Jakarta Barat 11480 \\ nsari@binus.edu
}

\begin{abstract}
This study aims to provide an overview of the disclosure of Corporate Social Responsibility (CSR) in the mining company's corporate sustainability report. It is also to analyze the disclosure of Corporate Social Responsibility (CSR) in corporate sustainability report with standard Global Reporting Initiatives (GRI) 3.1. Research was conducted in Batubara Bukit Asam (Persero) Tbk. and Timah (Persero) Tbk. on their corporate sustainability report for the year of 2012. The analysis was conducted on the presentation of economic performance indicator, environmental performance indicator, performance indicators of employment and workplace practices, human rights performance indicator, public performance indicator and performance indicator reported products liability provisions established in the GRI 3.1. The result is the two companies have disclosed CSR in accordance with GRI3.1. Batubara Bukit Asam (Persero) Tbk and Timah (Persero) Tbk have disclosed their performance indicators; and the average has exceeded 75\%. However, the disclosure of each indicator and its aspects are not comprehensive.
\end{abstract}

Keywords: Corporate Social Responsibility (CSR), Global Reporting Initiative (GRI), performance indicator

\begin{abstract}
ABSTRAK
Penelitian ini bertujuan untuk memberikan gambaran mengenai pengungkapan Corporate Social Responsibility (CSR) dalam laporan keberlanjutan perusahaan perusahaan tambang. Penelitian juga menganalisis pengungkapan Corporate Social Responsibility (CSR) dalam laporan keberlanjutan perusahaan dengan standar Global Reporting Initiatives (GRI) 3.1. Penelitian dilakukan terhadap Batubara Bukit Asam (Persero) Tbk. dan Timah (Persero) Tbk. pada laporan keberlanjutan perusahaan untuk tahun 2012. Analisis dilakukan terhadap penyajian indikator kinerja ekonomi, indikator kinerja lingkungan hidup, indikator kinerja praktik ketenagakerjaan dan lingkungan kerja, indikator kinerja hak asasi manusia, indikator kinerja masyarakat dan indikator kinerja tanggung jawab produk yang dilaporkan dengan ketentuan yang ditetapkan pada GRI 3.1. Hasil yang diperoleh adalah kedua perusahaan sudah mengungkapkan CSR sesuai dengan GRI3.1. Batubara Bukit Asam (Persero) Tbk dan Timah (Persero) Tbk telah mengungkapan setiap indikator kinerja dan pengungkapan rata-rata sudah melebihi $75 \%$. Namun pengungkapan indikator dan masing-masing aspeknya masih belum rinci.
\end{abstract}

Kata kunci: Corporate Social Responsibility (CSR), Global Reporting Initiative (GRI), indikator kinerja 


\section{PENDAHULUAN}

Dengan berkembangnya kesadaran masyarakat akan lingkungan sekitar, maka perusahaan dituntut untuk tidak hanya untuk mencari keuntungan (profit oriented), tetapi perusahaan juga berlomba-lomba untuk melaksanakan tanggung jawab sosial. Diharapkan, dengan memberikan image yang baik dari perusahaan akan kesadaran terhadap lingkungan sekitar, perusahaan akan mendapatkan konsumen yang lebih banyak, lebih loyal, dan pada akhirnya akan meningkatkan keuntungan perusahaan. Di Indonesia konsep Corporate Social Responsibility (CSR) ini diatur dalam UndangUndang Republik Indonesia Nomor 40 Tahun 2007 tentang Perseroan Terbatas. Menurut UndangUndang Republik Indonesia Nomor 40 Tahun 2007 tentang Perseroan Terbatas, tanggung jawab sosial dan lingkungan (CSR) adalah komitmen perseroan untuk berperan serta dalam pembangunan ekonomi berkelanjutan yang berguna untuk meningkatkan kualitas kehidupan dan lingkungan yang bermanfaat, baik bagi perseroan sendiri, komunitas setempat, maupun masyarakat pada umumnya.

Konsep Corporate Social Responsibility (CSR) berfokus pada triple bottom line yakni economic prosperity, enviromental quality, social justice. Perusahaan dapat terus melanjutkan kegiatan usahanya dengan mengimplementasikan konsep triple bottom line ke dalam tiga aspek, yaitu keuntungan (profit), terlibat pada pemenuhan kesejahteraan masyarakat (people) dan menjaga kelestarian lingkungan (planet). Perusahaan mengungkapkan tindakan pertanggungjawaban sosial yang telah dilakukan oleh perusahaan kepada stakeholders dalam sustainability report (laporan keberlanjutan). Laporan keberlanjutan perusahaan memberikan gambaran yang seimbang dan wajar terhadap kinerja keberlanjutan dari organisasi atau perusahaan pelapor, termasuk kontribusi positif dan negatif yang telah mereka lakukan dalam periode tertentu.

Pedoman atau standar yang sering digunakan oleh perusahaan dalam melaporkan keberlanjutan perusahaan mereka yaitu Global Reporting Initiatives (GRI). Adapun standar GRI yang berlaku sekarang adalah GRI G3.1 yang merupakan penyempuranaan dari standar-standar sebelumnya. GRI G3.1 memberikan prinsip-prinsip dalam mendefinisikan isi laporan dan menjamin kualitas dari informasi yang dilaporkan dalam hal pelaporan keberlanjutan perusahaan. Kerangka pelaporan yang disusun dalam Global Reporting Initiative membagi aspek pelaporan ke dalam enam aspek, dimana setiap aspek berisi protokol indikator (indikator kinerja). Keenam aspek atau indikator tersebut adalah indikator kinerja ekonomi, indikator kinerja lingkungan hidup, indikator kinerja praktik ketenagakerjaan dan lingkungan kerja, indikator kinerja hak asasi manusia, indikator kinerja masyarakat, dan indikator kinerja tanggung jawab produk.

Penelitian ini menganalisis dan membandingkan tingkat pengungkapan tanggung jawab sosial perusahaan dalam GRI G3.1 dengan laporan keberlanjutan perusahaan (sustainability reporting) tahun 2012 pada perusahaan tambang Batubara Bukit Asam (Persero) Tbk. dan Timah (Persero) Tbk. Penelitian ini mengembangkan penelitian terdahulu yang dilakukan Budisusetyo dan Almilia (2008) yang membandingkan mengenai pengungkapan Internet Sustainability Reporting pada perusahaan yang terdaftar di Bursa Efek Indonesia tahun 2008 dan mengembangkan penelitian yang dilakukan Defri (2012) yang menganalisis pengungkapkan Corporate Social Responsibility (CSR) pada perusahaan pertambangan berdasarkan GRI G3.

Penelitian ini mempunyai identifikasi masalah sebagai berikut. Pertama, bagaimana tingkat pengungkapan corporate social responsibility dalam laporan keberlanjutan yang diterbitkan perusahaan tambang Batubara Bukit Asam (Persero) Tbk dan Timah (Persero) Tbk. tahun 2012 dengan setiap indikator kinerja dalam standar Global Reporting Initiative G3.1. Kedua, bagaimana pengungkapan dan pengaruh suplemen indikator mining and metal (MM) dalam setiap indikator kinerja GRI G3.1. Ketiga, bagaimana tingkat pelaporan CSR perusahaan secara keseluruhan.

Sesuai dengan perumusan masalah, penelitian menganalisis bagaimana kesesuaian pengungkapan CSR dalam laporan keberlanjutan perusahaan pada tahun 2012 yang dibuat oleh 
perusahaan tambang Batubara Bukit Asam (Persero) Tbk dan Timah (Persero) Tbk dengan standar GRI 3.1. Kesesuaian pengungkapan tersebut yaitu untuk indikator kinerja ekonomi, indikator kinerja lingkungan hidup, indikator kinerja praktik ketenagakerjaan dan lingkungan kerja, indikator kinerja hak asasi manusia, indikator kinerja masyarakat, dan indikator kinerja tanggung jawab produk. Penelitian ini diharapkan dapat memperoleh bagaimana tingkat pengungkapan CSR pada perusahaan tambang Batubara Bukit Asam (Persero) Tbk, dan Timah (Persero) Tbk.

\section{METODE}

Penelitian ini menggunakan metode kualitatif dalam bentuk studi literatur dengan tujuan untuk menganalisis penerapan standar GRI 3.1 yaitu untuk indikator indikator kinerja ekonomi, indikator kinerja lingkungan hidup, indikator kinerja praktik ketenagakerjaan dan lingkungan kerja, indikator kinerja hak asasi manusia, indikator kinerja masyarakat dan indikator kinerja tanggung jawab produk dalam laporan keberlanjutan perusahaan (sustainability reporting) perusahaan tambang pada 2012. Perusahaan Batubara Bukit Asam (Persero) Tbk, dan Timah (Persero) Tbk dipilih sebagai objek dan sampel penelitian karena kemungkinan terdapat fakta menarik untuk dianalisis berdasarkan tujuan penelitian ini. Adapun kode perusahaan pada BEI untuk kedua perusahaan ini adalah PTBA (Batubara Bukit Asam) dan TINS (Timah).

Data yang digunakan di dalam penelitian ini adalah data sekunder dari perusahaan-perusahaan sektor bahan tambang di BEI tahun 2012, yaitu Perusahaan Batubara Bukit Asam (Persero) Tbk dan Timah (Persero) Tbk. Data yang digunakan adalah laporan tahunan perusahaan (annual report), laporan keberlanjutan perusahaan (sustainability report) yang berdasarkan standar GRI 3.1. Peneltian menggunakan data pendukung dari situs resmi perusahaan. Untuk menunjang penelitian ini, penulis menggunakan standar mengenai pelaporan CSR yakni standar Global Reporting Initiative G3.1. Data yang didapatkan dari penelitan akan disajikan dalam bentuk tabel yang berisi mengenai penentuan skala likert dalam penerapan indeks Global Reporting Initiative (disajikan dalam bentuk angka 0-4), sehingga dapat diketahui perusahaan mana yang mengungkapkan pelaporan CSR secara jelas dan menyeluruh. Selain penjelasan menggunakan tabel, penjelasan juga akan dilakukan dalam bentuk paragraf yang berisi simpulan dari tabel setiap indikator. Penggunaan skala Likert dalam penelitian ini untuk memberikan skor penilaian terhadap indikator pengungkapan CSR yang dilakukan perusahaan sektor bahan tambang yang terdaftar di BEI pada 2013 yang disesuaikan dengan standar pengungkapan berdasarkan kerangka pelaporan Global Reporting Initiative. Skor yang diberikan didasarkan pada tingkat informasi yang disampaikan dalam laporan CSR perusahaan. Kriteria dalam pemberian skor tersebut yaitu seperti pada Tabel 1 .

Tabel 1 Skala Likert terhadap indikator pengungkapan CSR

\begin{tabular}{cl}
\hline Skor & \multicolumn{1}{c}{ Keterangan } \\
\hline 0 & Perusahaan tidak memberikan penjelasan untuk indikator \\
1 & Perusahaan hanya menyebutkan indikator tanpa adanya penjelasan \\
2 & Perusahaan menyebutkan indikator dan memberikan penjelasan secara singkat \\
3 & $\begin{array}{l}\text { Perusahaan menyebutkan indicator dan memberikan penjelaskan dengan beberapa } \\
\text { detail atau rincian. }\end{array}$ \\
4 & Perusahaan menjelaskan indikator secara lengkap dan rinci \\
\hline
\end{tabular}

Pembahasan dimulai dengan melihat secara umum laporan laporan keberlanjutan perusahaan (sustainability reporting) tahun 2012 perusahaan Batubara Bukit Asam (Persero) Tbk dan Timah (Persero) Tbk. Laporan laporan keberlanjutan perusahaan (sustainability reporting) tersebut kemudian dianalisis untuk mengetahui apakah perusahaan Batubara Bukit Asam (Persero) Tbk dan Timah 
(Persero) Tbk telah mengungkapkan keenam indikator yang ada pada standar GRI 3.1 yaitu untuk indikator indikator kinerja ekonomi, indikator kinerja lingkungan hidup, indikator kinerja praktik ketenagakerjaan dan lingkungan kerja, indikator kinerja hak asasi manusia, indikator kinerja masyarakat, dan indikator kinerja tanggung jawab produk. Analisis tersebut akan diklasifikasikan dengan menggunakan skala Likert. Pembahasan diakhiri dengan mengambil simpulan mengenai tingkat pengungkapan Corporate Social Responsibility dalam laporan keberlanjutan yang diterbitkan perusahaan perusahaan Batubara Bukit Asam (Persero) Tbk dan Timah (Persero) Tbk dengan setiap indikator kinerja yang tertera dalam standar Global Reporting Initiative G3.1.

\section{HASIL DAN PEMBAHASAN}

\section{Pengungkapan Indikator Kinerja Ekonomi (EC)}

Tabel 2 dan Tabel 3 memberikan informasi mengenai tingkat pengungkapan dari masingmasing indikator kinerja ekonomi (EC).

Tabel 2 Pengungkapan Indikator Kinerja Ekonomi (EC)

\begin{tabular}{ccccc}
\hline \multirow{2}{*}{ NO } & \multirow{2}{*}{ ASPEK } & \multirow{2}{*}{ KODE } & \multicolumn{2}{c}{ KODE SAHAM EMITEN } \\
& & PC1 & 3 & TINS \\
\hline 1 & & MM & 0 & 0 \\
2 & \multirow{3}{*}{ Aspek : Kinerja Ekonomi } & EC2 & 3 & 0 \\
3 & & EC3 & 3 & 2 \\
4 & & EC4 & 2 & 2 \\
5 & Aspek: Keberadaan Pasar & EC5 & 2 & 2 \\
6 & & EC6 & 2 & 4 \\
7 & & EC7 & 4 & 4 \\
8 & & MM & 3 & 4 \\
9 & Aspek: Akibat Tidak Langsung & EC8 & 4 & 3 \\
10 & & EC9 & 4 & 4 \\
11 & & &
\end{tabular}

Tabel 3 Persentase Pengungkapan Setiap Aspek dalam Indikator Ekonomi

\begin{tabular}{lccc}
\hline $\begin{array}{c}\text { Kode Saham } \\
\text { Perusahaan }\end{array}$ & $\begin{array}{c}\text { Pengungkapan } \\
\text { Maksimal }\end{array}$ & $\begin{array}{c}\text { Total } \\
\text { Pengungkapan }\end{array}$ & $\begin{array}{c}\% \\
\text { Pengungkapan }\end{array}$ \\
\hline PTBA & 12 & 10 & $83.3 \%$ \\
TINS & 12 & 10 & $83.3 \%$ \\
\hline
\end{tabular}

Dalam pengungkapan indikator kinerja ekonomi, Batubara Bukit Asam (Persero) Tbk kurang menjelaskan mengenai rentang rasio standar upah terendah dibandingkan dengan upah minimum setempat pada daerah operasi utama. Berdasarkan jenis kelamin (EC5) hanya dijelaskan dengan chart tanpa diberikan rincian atau penjelasan lebih lanjut. Kemudian Batubara Bukit Asam (Persero) Tbk juga kurang menjelaskan definisi pemasok lokal dan proporsi pengeluaran (EC6).

Dalam pengungkapan indikator kinerja ekonomi, Timah (Persero) Tbk kurang menjelaskan mengenai implikasi finansial dan risiko lainnya akibat perubahan iklim serta peluangnya bagi aktivitas organisasi (EC2) dan skema pembayaran program manfaat pasti secara jelas (EC3). Timah (Persero) Tbk hanya menjelaskan bahwa program manfaat pasti diatur oleh pihak asuransi yang bekerja-sama dengan perusahaan. 
Batubara Bukit Asam (Persero) Tbk dan Timah (Persero) Tbk menyatakan dalam laporan keberlanjutan perusahaan pada 2012 bahwa perusahaan tidak pernah menerima bantuan finansial signifikan yang diterima dari pemerintah (EC4). Namun seharusnya, sebagai BUMN (Badan Usaha Milik Negara), Batubara Bukit Asam (Persero) Tbk dan PT Timah (Persero) mengungkapan persentase kepemilikan saham yang dimiliki oleh pemerintah. Kedua perusahaan juga tidak mengungkapkan indikator suplemen untuk sektor bahan (MM) yaitu mengenai pembayaran atas penggunaan (pemanfaatan) lahan dan penjelasan ditambahkan pada Extractive Industries Transparency Initiative (EITI).

\section{Pengungkapan Indikator Kinerja Lingkungan (EN)}

Tabel 4 dan Tabel 5 memberikan informasi mengenai tingkat pengungkapan dari masingmasing indikator kinerja Kinerja Lingkungan (EN).

Tabel 4 Pengungkapan Indikator Kinerja Lingkungan (EN)

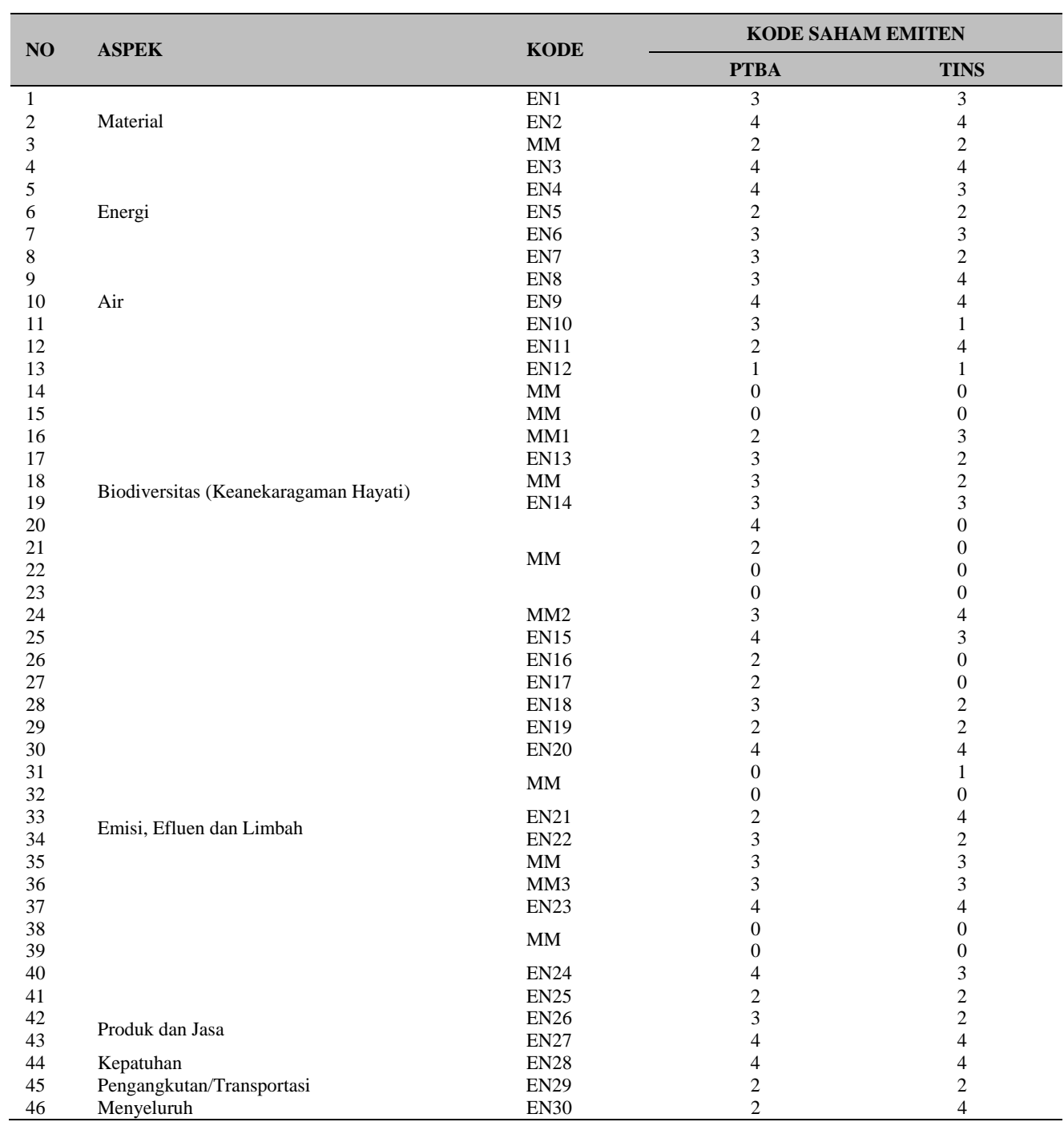


Tabel 5 Persentase Pengungkapan Setiap Aspek dalam Indikator Kinerja Lingkungan

\begin{tabular}{cccc}
\hline Kode Saham Perusahaan & Pengungkapan Maksimal & $\begin{array}{c}\text { Total } \\
\text { Pengungkapan }\end{array}$ & \% Pengungkapan \\
\hline PTBA & 46 & 38 & $82.61 \%$ \\
TINS & 46 & 35 & $76.09 \%$ \\
\hline
\end{tabular}

Indikator kinerja lingkungan adalah indikator terendah yang diungkapkan oleh kedua perusahaan. Hal ini mungkin disebabkan pada indikator ini terdapat paling banyak hal yang harus diungkapkan perusahaan. Batubara Bukit Asam (Persero) Tbk dan Timah (Persero) Tbk tidak menjelaskan mengenai dampak signifikan yang diakibatkan oleh aktivitas, produk, dan jasa organisasi pelapor terhadap keanekaragaman hayati di daerah yang diproteksi (dilindungi) dan di daerah yang memiliki keanekaragaman hayati bernilai tinggi di luar daerah yang diproteksi (dilindungi) (EN12). Kedua perusahaan juga kurang menjelaskan mengenai suplemen indikator (MM) yang ada dalam indikator kinerja lingkungan ini.

\section{Pengungkapan Indikator Kinerja Masyarakat (SO)}

Tabel 6 dan Tabel 7 memberikan informasi mengenai tingkat pengungkapan dari masingmasing indikator kinerja masyarakat (SO).

Tabel 6 Pengungkapan Indikator Kinerja Masyarakat (SO)

\begin{tabular}{|c|c|c|c|c|}
\hline \multirow{2}{*}{ No } & \multirow{2}{*}{ Aspek } & \multirow{2}{*}{ Kode } & \multicolumn{2}{|c|}{ Kode Saham Emiten } \\
\hline & & & PTBA & TINS \\
\hline 1 & \multirow{8}{*}{ Komunitas Lokal } & SO1 & 1 & 2 \\
\hline 2 & & & 0 & 2 \\
\hline 3 & & MM & 0 & 0 \\
\hline 4 & & & 0 & 0 \\
\hline 5 & & MM6 & 3 & 4 \\
\hline 6 & & MM7 & 4 & 0 \\
\hline 7 & & SO9 & 3 & 0 \\
\hline 8 & & SO10 & 3 & 0 \\
\hline 9 & Pertambangan Artisanal Dan Skala Kecil & MM8 & 2 & 3 \\
\hline 10 & Pemindahan Tempat Tinggal & MM9 & 3 & 4 \\
\hline 11 & Rencana Penutupan & MM10 & 2 & 3 \\
\hline 12 & \multirow{3}{*}{ Korupsi } & $\mathrm{SO} 2$ & 2 & 4 \\
\hline 13 & & SO3 & 3 & 3 \\
\hline 14 & & $\mathrm{SO} 4$ & 2 & 2 \\
\hline 15 & \multirow{2}{*}{ Kebijakan Publik } & SO5 & 3 & 4 \\
\hline 16 & & SO6 & 4 & 4 \\
\hline 17 & Kelakuan Tidak Bersaing & SO7 & 4 & 4 \\
\hline 18 & \multirow[b]{2}{*}{ Kepatuhan } & SO8 & 4 & 4 \\
\hline 19 & & MM & 0 & 0 \\
\hline
\end{tabular}

Tabel 7 Persentase Pengungkapan Setiap Aspek dalam Indikator Kinerja Masyarakat

\begin{tabular}{lccc}
\hline Kode Saham Perusahaan & Pengungkapan Maksimal & Total Pengungkapan & \% Pengungkapan \\
\hline PTBA & 19 & 15 & $78.95 \%$ \\
TINS & 19 & 13 & $68.42 \%$ \\
\hline
\end{tabular}


Dalam pengungkapan indikator kinerja masyarakat, Batubara Bukit Asam (Persero) Tbk dan Timah (Persero) Tbk kurang menjelaskan mengenai persentase operasi dengan mengimplementasikan keterlibatan komunitas lokal, dampak penilaian dan program pembangunan (SO1). Selain itu, kedua perusahaan tidak melaporkan mengenai kasus korupsi atau dugaan kasus korupsi yang terjadi di perusahaan selama tahun 2012 (SO4). Kedua perusahaan juga sedikit sekali menjelaskan mengenai suplemen indikator (MM) yang ada dalam indikator kinerja masyarakat ini.

Ada beberapa indikator yang tidak dijelaskan oleh Timah (Persero) Tbk. Hal tersebut di antaranya seperti operasi yang memiliki potensi signifikan atau dampak negatif aktual terhadap komunitas lokal (SO9). Perusahaan juga tidak menjelaskan hal-hal yang dilakukan dalam pencegahan dan implementasi mitigasi dalam operasi yang memiliki potensi signifikan atau dampak negatif aktual terhadap komunitas lokal (SO10).

\section{Pengungkapan Indikator Tanggung Jawab Produk (PR)}

Tabel 8 dan Tabel 9 memberikan informasi mengenai tingkat pengungkapan dari masingmasing indikator tanggung jawab produk (PR).

Tabel 8 Pengungkapan Indikator Tanggung Jawab Produk (PR)

\begin{tabular}{cllcc}
\hline \multirow{2}{*}{ No } & \multirow{2}{*}{ Aspek } & \multirow{2}{*}{ Kode } & \multicolumn{2}{c}{ Kode Saham Emiten } \\
\cline { 3 - 5 } & & & PTBA & TINS \\
\hline 1 & Tanggung Jawab Terhadap Produk & MM11 & 3 & 2 \\
2 & Kesehatan dan Keselamatan Pelanggan & PR1 & 3 & 2 \\
3 & PR2 & 4 & 4 \\
4 & \multirow{2}{*}{ Pemasangan Label bagi Produk dan Jasa } & PR3 & 3 & 3 \\
5 & PR4 & 3 & 4 \\
6 & & PR5 & 3 & 2 \\
7 & \multirow{2}{*}{ Komunikasi Pemasaran } & PR6 & 3 & 3 \\
8 & \multirow{2}{*}{ Keleluasaan Pribadi Pelanggan } & PR7 & 4 & 4 \\
9 & PR8 & 4 & 4 \\
10 & Kepatuhan & PR9 & 3 & 4 \\
\hline
\end{tabular}

Tabel 9 Persentase Pengungkapan Setiap Aspek dalam Indikator Tanggung Jawab Produk

\begin{tabular}{lccc}
\hline Kode Saham Perusahaan & $\begin{array}{c}\text { Pengungkapan } \\
\text { Maksimal }\end{array}$ & $\begin{array}{c}\text { Total } \\
\text { Pengungkapan }\end{array}$ & $\begin{array}{c}\% \\
\text { Pengungkapan }\end{array}$ \\
\hline ANTM & 10 & 10 & $100.00 \%$ \\
INCO & 10 & 10 & $100.00 \%$ \\
PTBA & 10 & 10 & $100.00 \%$ \\
TINS & 10 & 10 & $100.00 \%$ \\
\hline
\end{tabular}

Untuk indikator tanggung jawab produk, baik Batubara Bukit Asam (Persero) Tbk maupun Timah (Persero) Tbk sudah mengungkap seluruh aspek walaupun pengungkapan dan penjelasannya belum rinci. Kedua perusahaan mengungkapkan seluruh aspek mengenai produk mereka dikarenakan indikator ini mencerminkan pengetahuan perusahaan mengenai produk mereka dan juga tanggung jawab perusahaan mengenai produk yang mereka produksi. 


\section{Pengungkapan Indikator Kinerja Praktik Tenaga Kerja dan Pekerjaan yang Layak (LA)}

Tabel 10 dan Tabel 11 memberikan informasi mengenai tingkat pengungkapan dari masingmasing indikator kinerja praktik tenaga kerja dan pekerjaan yang layak (LA).

Tabel 10 Pengungkapan Indikator Kinerja Praktik Tenaga Kerja dan Pekerjaan yang Layak (LA)

\begin{tabular}{|c|c|c|c|c|}
\hline \multirow{2}{*}{ No } & \multirow{2}{*}{ Aspek } & \multirow{2}{*}{ Kode } & \multicolumn{2}{|c|}{ Kode Saham Emiten } \\
\hline & & & PTBA & TINS \\
\hline 1 & \multirow{3}{*}{ Pekerjaan } & LA1 & 3 & 4 \\
\hline 2 & & LA2 & 2 & 4 \\
\hline 3 & & LA3 & 4 & 3 \\
\hline 4 & \multirow{3}{*}{ Tenaga kerja / Hubungan Manajemen } & LA4 & 2 & 2 \\
\hline 5 & & LA5 & 4 & 2 \\
\hline 6 & & MM4 & 4 & 4 \\
\hline 7 & \multirow{5}{*}{ Kesehatan dan Keselamatan Jabatan } & LA6 & 4 & 3 \\
\hline 8 & & LA7 & 2 & 4 \\
\hline 9 & & MM & 0 & 0 \\
\hline 10 & & LA8 & 3 & 1 \\
\hline 11 & & LA9 & 1 & 3 \\
\hline 12 & \multirow{3}{*}{ Pelatihan dan Pendidikan } & LA10 & 4 & 3 \\
\hline 13 & & LA11 & 3 & 3 \\
\hline 14 & & LA12 & 4 & 3 \\
\hline 15 & \multirow{2}{*}{ Keberagaman dan Kesempatan Setara } & LA13 & 3 & 2 \\
\hline 16 & & LA14 & 3 & 3 \\
\hline
\end{tabular}

Tabel 11 Persentase Pengungkapan Setiap Aspek dalam Indikator Kinerja Praktik Tenaga Kerja dan Pekerjaan yang Layak

\begin{tabular}{lccc}
\hline Kode Saham Perusahaan & $\begin{array}{c}\text { Pengungkapan } \\
\text { Maksimal }\end{array}$ & $\begin{array}{c}\text { Total } \\
\text { Pengungkapan }\end{array}$ & $\begin{array}{c}\% \\
\text { Pengungkapan }\end{array}$ \\
\hline PTBA & 16 & 15 & $93.75 \%$ \\
TINS & 16 & 15 & $93.75 \%$ \\
\hline
\end{tabular}

Timah (Persero) Tbk tidak melaporkan pelaksanaan mengenai program pendidikan, pelatihan, penyuluhan/ bimbingan, pencegahan, pengendalian risiko setempat untuk membantu para karyawan, anggota keluarga, dan anggota masyarakat mengenai penyakit berat/berbahaya (LA8). Batubara Bukit Asam (Persero) Tbk tidak menjelaskan mengenai masalah kesehatan dan keselamatan yang tercakup dalam perjanjian resmi dengan serikat karyawan (LA9). Kedua perusahaan juga kurang menjelaskan mengenai suplemen indikator (MM) yang ada dalam indikator kinerja lingkungan ini.

\section{Pengungkapan Indikator Kinerja Hak Asasi Manusia (HR)}

Tabel 12 dan Tabel 13 memberikan informasi mengenai tingkat pengungkapan dari masingmasing indikator kinerja hak asasi manusia (HR). 
Tabel 12 Pengungkapan Indikator Kinerja Hak Asasi Manusia (HR)

\begin{tabular}{cllcc}
\hline \multirow{2}{*}{ Nospek } & \multicolumn{2}{c}{ Kode } & \multicolumn{2}{c}{ Kode Saham Emiten } \\
\cline { 3 - 5 } & & & PTBA & TINS \\
\hline 1 & & HR1 & 2 & 1 \\
2 & (Praktik) Investasi dan Pengadaan & HR2 & 4 & 1 \\
3 & & HR3 & 0 & 4 \\
4 & Non-diskriminasi & HR4 & 4 & 4 \\
5 & Kebebasan Berserikat dan Perjanjian & HR5 & 2 & 2 \\
6 & Bersama & MM & 3 & 4 \\
7 & Pekerja Anak & HR6 & 4 & 4 \\
8 & Kerja Paksa dan Kerja Tertib & HR7 & 4 & 3 \\
9 & Praktik/Tindakan Pengamanan & HR8 & 3 & 0 \\
10 & & MM5 & 4 & 4 \\
11 & & HR9 & 4 & 4 \\
12 & Hak Penduduk Asli & HR10 & 3 & 4 \\
\hline
\end{tabular}

Tabel 13 Persentase Pengungkapan Setiap Aspek dalam Indikator Kinerja Hak Asasi Manusia

\begin{tabular}{lccc}
\hline Kode Saham Perusahaan & Pengungkapan Maksimal & $\begin{array}{c}\text { Total } \\
\text { Pengungkapan }\end{array}$ & $\begin{array}{c}\% \\
\text { Pengungkapan }\end{array}$ \\
\hline PTBA & 13 & 12 & $92.31 \%$ \\
TINS & 13 & 11 & $84.62 \%$ \\
\hline
\end{tabular}

Dalam aspek mengenai persentase dan jumlah perjanjian investasi signifikan yang memuat klausula HAM atau telah menjalani proses screening/filtering terkait dengan aspek HAM (HR1), Batubara Bukit Asam (Persero) Tbk tidak mengungkapkan secara detail perjanjian mengenai HAM. Timah (Persero) Tbk tidak melaporkan jumlah dan persentase perjanjian investasi signifikan yang memasukkan klausula HAM.

Pada Timah (Persero) Tbk persentase pemasok dan rekanan bisnis lainnya yang signifikan telah menjalani proses screening/filtering atas aspek HAM (HR2). Batubara Bukit Asam (Persero) Tbk tidak melakukan pelatihan bagi karyawan mengenai kebijakan dan serta prosedur terkait dengan aspek HAM yang relevan dengan kegiatan organisasi, termasuk persentase karyawan yang telah menjalani pelatihan selama tahun 2012 (HR3).

\section{Pengungkapan Keseluruhan Aspek}

Tabel 14 menginformasikan perbandingan pengungkapan seluruh aspek dalam indikator kinerja laporan keberlanjutan perusahaan.

Tabel 14 Pengungkapan Seluruh Indikator dalam GRI 3.1

\begin{tabular}{lccc}
\hline Indikator Kinerja & $\begin{array}{c}\text { Pengungkapan } \\
\text { Maksimal }\end{array}$ & \multicolumn{2}{c}{ Kode Saham Perusahaan } \\
\cline { 2 - 4 } & & PTBA & 10 \\
\hline Ekonomi (EC) & 12 & 10 & 35 \\
Lingkungan (EN) & 46 & 38 & 13 \\
Masyarakat (SO) & 19 & 10 & 10 \\
Tanggung Jawab Produk (PR) & 10 & 15 & 15 \\
Praktik Tenaga Kerja dan Pekerjaan yang Layak (LA) & 16 & 12 & 11 \\
Hak Asasi Manusia (HR) & 13 & 100 & 94 \\
Total Pengungkapan & 116 & $86.21 \%$ & $81.03 \%$ \\
\hline Pengungkapan Rata-Rata & $100 \%$ & \multicolumn{2}{c}{}
\end{tabular}




\section{SIMPULAN}

Berdasarkan hasil analisis, kedua perusahaan sudah mengungkapkan GRI 3.1 dengan baik. Batubara Bukit Asam (Persero) Tbk dan Timah (Persero) Tbk telah mengungkapan setiap indikator kinerja dan pengungkapan rata-rata sudah melebihi $75 \%$. Akan tetapi, pengungkapan indikator beserta masing-masing aspeknya masih belum rinci. Berdasarkan Tabel 14, diperoleh simpulan bahwa indikator tanggung jawab produk (PR) merupakan indikator kinerja dengan pengungkapan tertinggi yang dilakukan oleh setiap perusahaan. Hal ini berkaitan dengan suplemen indikator (MM) pada indikator kinerja tanggung jawab produk (PR) yang hanya berjumlah satu suplemen indikator sehingga memudahkan perusahaan dalam mengungkapkan setiap aspek dalam indikator PR. Di sisi lain kedua perusahaan mengungkapkan seluruh aspek mengenai produk mereka (PR) karena indikator ini mencerminkan pengetahuan perusahaan mengenai produk mereka dan juga tanggung jawab perusahaan mengenai produk yang mereka produksi.

Sebagai saran dari penelitian adalah Batubara Bukit Asam (Persero) Tbk dan Timah (Persero) Tbk untuk lebih mengungkapkan indikator kinerja lingkungan (EN) dan indikator kinerja masyarakat (SO) yang berdasarkan standar GRI 3.1 di dalam laporan keberlanjutan perusahaan beserta dengan suplemen indikator (MM) di setiap indikator kinerja.

\section{DAFTAR PUSTAKA}

Bouten, L., Everaert, P., Liedekerke, L.V., Moor, L. D. (2011). Corporate Social Responsibility reporting: A comprehensive picture? Accounting Forum, 35, 187- 204.

Budisusetyo, S., and Almilia, L. S. (2008). Exploring financial and sustainability reporting on the web in Indonesia. Diakses dari SSRN: http://ssrn.com/abstract=1219449 atau http://dx.doi.org/10.2139/ssrn.1219449

Bukit Asam. (n.d.) Laporan Keberlanjutan 2012. Diakses 5 Mei 2014 dari http://ptba.co.id/assets/datafiles/SustainabilityReportPTBA2012.pdf.

Defri. (2012). Analisis Perbandingan Pengungkapan Corporate Social Responsibility (CSR) pada Perusahaan Tambang yang Terdaftar di BEI tahun 2011 berdasarkan Global Reporting Initiatives (GRI) G3.1. Skripsi S1. Jakarta: Universitas Bina Nusantara.

Timah. (n.d.) Laporan Keberlanjutan 2012. Diakses 5 Mei 2014 dari http://www.timah.com/v2/ina/report/110052010020953/laporan tahunan/719042013123527/laporan-tahunan-2012/. 